\title{
Variability, Heritability and Genetic Advance for Yield and Yield Attributing Characters in Dolichos Bean (Dolichos lablab L.) Genotypes under Hill Zone of Karnataka
}

\author{
M. L. Shilpa ${ }^{1 *}$, V. Srinivasa ${ }^{1}$, Devaraju' ${ }^{1}$, S. Gangaprasad ${ }^{2}$, \\ M. Ganapathi ${ }^{3}$ and A. Akshay ${ }^{3}$
}

${ }^{1}$ Department of Vegetable Science, ${ }^{3}$ Department of Crop Physiology, College of Horticulture, Mudigere, Karnataka, India

${ }^{2}$ Department of Genetics and Plant Breeding, College of Agriculture, Shivamogga, Karnataka, India

*Corresponding author

\section{A B S T R A C T}

\section{Keywords}

Dolichos bean, Variability, Heritability, Genetic Advance, GCV and PCV

\section{Article Info}

Accepted:

04 September 2020 Available Online: 10 October 2020

\begin{abstract}
An investigation was conducted on studies on genetic variability for yield and yield attributing characters in dolichos bean (Dolichos lablab L.). Analysis of variance revealed highly significant differences among the genotypes for most of the characters under the study. The range, genotypic and phenotypic coefficient of variation, heritability, genetic advance and genetic advance as per cent of mean were calculated. The genotypes showed considerable amount of variability for all the traits. High heritability coupled with high genetic advance as per cent of mean was recorded for plant height at harvest, number of leaves per plant at harvest, days to first flowering, days to 50 per cent flowering, number of flowers per cluster, pod length, pod width and pod thickness, number of pods per cluster, number of pods per plant, average pod weight, average green seed weight, pod yield per plant, pod yield per plot, pod yield per hectare and shelling per cent, which illustrates that these characters are under the influence of additive gene action. Thus, there is a bountiful scope for improving these attributes through direct selection.
\end{abstract}

\section{Introduction}

Dolichos bean is an important leguminous vegetable originated in India. Dolichos Bean is also called as Indian bean, lablab bean, sem or hyacinth bean belongs to the family leguminaceae with chromosome number of $2 n=22 / 24$. It is a multi-utility and multibeneficial leguminous crop, grown for vegetable, pulse, fodder, green manure, cover crop, medicine and ornamental purpose. It is one of the oldest legume crop known to be cultivated in dry and semi-arid regions of Asia, Africa and America (Ayyangar and Nambiar, 1935). In India, it is popularly grown in South, East and North-Eastern parts of the country.

The crop has important value in agricultural economy of the country and importance as 
pulse and vegetable crop in human diet. It is a very nutritious vegetable grown in the cool season throughout the world. It is grown as vegetable crop for fresh seeds and as pulse for dried seed. Dolichos bean is rich in proteins, minerals, vitamins and fibers. It's fresh pods contain 86.1 per cent moisture, 3.8 per cent protein, 6.7 per cent carbohydrate, 0.7 per cent fat, 0.9 per cent mineral matter, $312 \mathrm{IU}$ vitamin-A and it is also good source of vitamin $\mathrm{B}$ and $\mathrm{C}$.

Nutritional analysis revealed that the dry seed contained 33 per cent starch as the major component, protein 25 per cent, a very low fat content 0.8 per cent and high dietary fiber 7.2 per cent.

Hyacinth bean is a herbaceous annual plant. Leaves are alternate and trifoliate. Flowers are borne in axillary racemes and are typically papilionaceous and are self-pollinated. Flowering takes place under short day periods irrespective of planting time. Anthesis occurs from 9 a.m. to 5 p.m. Anther dehiscence is from 5.00 a.m. to 2.00 p.m. Stigma is receptive on the day of anthesis (Pokle and Deshmukh, 1972).

A wide range of genetic variability is available in dolichos bean since it is originated in India, providing good scope for improvement in yield and associated characters through selection. The exploitation of genetic variability in available germplasm is a pre-requisite for identification and development of new improved high yielding genotypes to boost the yield potential of crop.

The variability available in the crop measures the possibility of improvement of any crop. Hence, it is essential to partition the variability into heritable and non- heritable components with the help of genetic parameters like genetic coefficient of variability, heritability and genetic advance.
Keeping the above points in view, the present study was conducted to study the genetic variability for yield and yield attributing characters in dolichos bean.

\section{Materials and Methods}

The present investigation was carried out at the Department of Vegetable Science, College of Horticulture, Mudigere, University of Agricultural and Horticultural Sciences. Shivamogga during the Rabi 2019-2020. Thirty genotypes of dolichos bean were procured from different sources like UAHS, Shivamogga, CHES, Godra, Gujarat, IIHR, Bangalore and NBPGR, New Delhi, have been taken for investigation.

The experiment was laid out in a randomized complete block design (RCBD) with two replications. The treatments in each replication were allotted randomly by using random number table. Dolichos bean seeds were sown in each replication with $1.5 \mathrm{~m} \times$ $1.2 \mathrm{~m}$ plot size at $45 \mathrm{~cm} \times 30 \mathrm{~cm}$ spacing. The crop was raised by following the recommended package of practices of University of Horticultural Sciences, Bagalkot (Plate 1).

Observations were recorded on five randomly selected plants in each replication for different traits viz., plant height, number of primary branches, number of leaves per plant, days to first flowering, days to 50 per cent flowering, days to first picking, number of pods per cluster, number of pods per plant, pod weight, number of seeds per pod, green seed weight, shelling per cent, pod length, pod width, pod thickness, hundred seed weigh and pod yield per plant.

Analysis of variance was performed by following the standard procedure given by Panse and Sukhatme (1967). Genotypic and phenotypic coefficients of variation were 
estimated according to Burton and Devane (1953) based on estimate of genotypic and phenotypic variance. The broad sense heritability $\left(\mathrm{h}^{2}\right)$ was estimated by following the procedure suggested by Weber and Moorthy (1952). Genetic advance and Genetic advance as per cent over mean for each character was predicted by the formula given by Johnson et al., Johnson et al., (1955).

\section{Results and Discussion}

Analysis of variance showed significant differences among the genotypes for all the characters studied at five per cent level of significance. The mean sum of squares for 18 yield and yield attributing characters in 30 genotypes of dolichos bean were presented in Table 1.

Components of variation exhibited by the genotypes for all the characters indicated wide range of variability present in the genotypes. A wide range of variability existing for various the quantitative traits has also been reported in dolichos bean by Verma et al., (2015), Chaudhari et al., (2016), Ram et al., (2016), Goudar et al., (2017), and Noorjahan et al., (2019). In general, phenotypic coefficients of variation were higher than genotypic coefficients of variation indicating that the genotypic influence is lessened under the influence of the given environment (Table 2).

Table.1 Analysis of variance for 18 yield and yield attributing crackers in thirty genotypes of dolichos bean

\begin{tabular}{|c|c|c|c|c|c|c|}
\hline \multirow[t]{2}{*}{$\begin{array}{l}\text { Sl. } \\
\text { No. }\end{array}$} & Source of variation /character & Replication & $\begin{array}{l}\text { Treatment } \\
\text { (genotypes) }\end{array}$ & Error & \multirow[t]{2}{*}{ S.Em. \pm} & \multirow[t]{2}{*}{$\begin{array}{c}\text { CD at } \\
5 \%\end{array}$} \\
\hline & Degrees of freedom & 1 & 29 & 29 & & \\
\hline 1 & Plant height at Harvest $(\mathrm{cm})$ & 9.13 & $207.34 * * *$ & 11.90 & 2.40 & 7.05 \\
\hline 2 & Number of primary branches at Harvest & 0.024 & $1.318 * *$ & 0.493 & 0.488 & 1.436 \\
\hline 3 & Number of leaves per plant at Harvest & 4.37 & $467.86 * * *$ & 4.82 & 1.53 & 4.49 \\
\hline 4 & Days to first flowering & 0.07 & $152.51 * * *$ & 9.00 & 2.09 & 6.13 \\
\hline 5 & Days to 50 per cent flowering & 8.82 & $125.15^{* * *}$ & 4.02 & 1.39 & 4.10 \\
\hline 6 & Number of flowers per cluster & 10.33 & $13.95 * * *$ & 2.11 & 1.01 & 2.97 \\
\hline 7 & Days to first picking & 14.02 & $209.54 * * *$ & 2.19 & 1.03 & 3.03 \\
\hline 8 & Number of pods per cluster & 1.67 & $6.80 * * *$ & 0.63 & 0.55 & 1.62 \\
\hline 9 & Number of pods per plant & 9.13 & $640.00 * * *$ & 10.84 & 2.29 & 6.73 \\
\hline 10 & Average pod weight (g) & 0.00 & $0.99 * * *$ & 0.02 & 0.10 & 0.30 \\
\hline 11 & Number of seeds per pod & 0.03 & $0.24 * * *$ & 0.02 & 0.10 & 0.29 \\
\hline 12 & Average green seed weight (g) & 0.00 & $0.01 * * *$ & 0.00 & 0.01 & 0.04 \\
\hline 13 & Pod yield per plant (g) & 14.00 & $1964.58 * * *$ & 42.92 & 4.55 & 13.40 \\
\hline 14 & Shelling per cent & 0.07 & $142.71 * * *$ & 0.04 & 0.13 & 0.40 \\
\hline 15 & Pod length $(\mathrm{cm})$ & 0.008 & $1.12 * * *$ & 0.040 & 0.14 & 0.41 \\
\hline 16 & Pod width $(\mathrm{cm})$ & 0.0004 & $0.09 * * *$ & 0.01 & 0.05 & 0.15 \\
\hline 17 & Pod thickness (mm) & 0.01 & $0.49 * * *$ & 0.04 & 0.13 & 0.40 \\
\hline 18 & Weight of 100 seeds (g) & 0.81 & $71.51 * * *$ & 1.05 & 0.71 & 2.10 \\
\hline
\end{tabular}

** significant at $5 \%$ level of significance 
Table.2 Mean, range and genetic components for morphological and yield parameters in dolichos bean germplasm

\begin{tabular}{|c|c|c|c|c|c|c|c|c|c|c|}
\hline \multirow[t]{2}{*}{ Characters } & \multirow[t]{2}{*}{ Mean \pm S.Em. } & \multicolumn{2}{|c|}{ Range } & \multirow[t]{2}{*}{ GV } & \multirow[t]{2}{*}{ PV } & \multirow{2}{*}{$\begin{array}{c}\text { GCV } \\
(\%)\end{array}$} & \multirow{2}{*}{$\begin{array}{c}\text { PCV } \\
(\%)\end{array}$} & \multirow{2}{*}{$\begin{array}{c}\mathbf{h}^{2} \\
(\%)\end{array}$} & \multirow[t]{2}{*}{ GA } & \multirow{2}{*}{$\begin{array}{c}\text { GAM } \\
(\%)\end{array}$} \\
\hline & & Min. & Max. & & & & & & & \\
\hline Plant height $(\mathrm{cm})$ at Harvest & $69.60 \pm 2.40$ & 54.50 & 92.30 & 97.72 & 109.62 & 14.20 & 15.04 & 89.10 & 19.23 & 27.63 \\
\hline $\begin{array}{l}\text { No. of primary branches at } \\
\text { Harvest }\end{array}$ & $5.41 \pm 0.49$ & 3.40 & 8.00 & 0.41 & 0.91 & 11.87 & 17.58 & 45.60 & 0.89 & 16.50 \\
\hline No. of leaves per plant at Harvest & $92.38 \pm 1.53$ & 46.50 & 108.60 & 231.52 & 236.34 & 16.47 & 16.64 & 98.00 & 31.02 & 33.58 \\
\hline Days to first flowering & $59.37 \pm 2.09$ & 38.50 & 71.50 & 71.76 & 80.76 & 14.27 & 15.18 & 88.90 & 16.45 & 27.71 \\
\hline Days to 50 per cent flowering & $70.05 \pm 1.40$ & 58.00 & 86.50 & 60.56 & 64.59 & 10.37 & 10.71 & 93.80 & 15.52 & 20.69 \\
\hline Number of flowers per cluster & $14.96 \pm 1.01$ & 9.30 & 21.30 & 5.92 & 8.03 & 16.27 & 18.95 & 73.70 & 4.30 & 28.77 \\
\hline Days to first picking & $112.29 \pm 1.03$ & 92.50 & 125.50 & 103.68 & 105.87 & 9.07 & 9.16 & 97.90 & 20.76 & 18.49 \\
\hline Number of pods per cluster & $9.29 \pm 0.55$ & 7.10 & 15.50 & 3.09 & 3.71 & 18.92 & 20.74 & 83.22 & 3.30 & 35.53 \\
\hline Number of pods per plant & $48.79 \pm 2.29$ & 32.95 & 122.85 & 314.58 & 325.42 & 36.35 & 36.97 & 96.70 & 35.92 & 73.62 \\
\hline Average pod weight (g) & $2.93 \pm 0.10$ & 1.60 & 5.70 & 0.48 & 0.50 & 23.65 & 24.18 & 95.60 & 1.40 & 47.63 \\
\hline Number of seeds per pod & $4.00 \pm 0.10$ & 3.40 & 5.10 & 0.11 & 0.13 & 8.21 & 8.95 & 84.20 & 0.62 & 15.53 \\
\hline Average green seed weight (g) & $0.43 \pm 0.02$ & 0.31 & 0.54 & 0.003 & 0.003 & 11.95 & 12.94 & 85.20 & 0.10 & 22.72 \\
\hline Pod yield per plant (g) & $139.18 \pm 4.55$ & 101.94 & 218.43 & 960.83 & 1003.75 & 22.30 & 22.76 & 95.70 & 62.47 & 44.85 \\
\hline Shelling per cent (\%) & $56.63 \pm 0.13$ & 26.27 & 66.78 & 71.34 & 71.37 & 14.92 & 14.92 & 99.90 & 17.39 & 30.72 \\
\hline Pod length (cm) & $5.21 \pm 0.14$ & 3.84 & 7.66 & 0.54 & 0.58 & 14.10 & 14.61 & 93.10 & 1.46 & 28.02 \\
\hline Pod width (cm) & $1.73 \pm 0.05$ & 1.17 & 2.09 & 0.04 & 0.05 & 12.13 & 12.88 & 88.70 & 0.41 & 23.55 \\
\hline Pod thickness (mm) & $5.31 \pm 0.13$ & 4.34 & 6.38 & 0.23 & 0.26 & 8.97 & 9.68 & 85.90 & 0.91 & 17.12 \\
\hline Weight of 100 seeds (g) & $40.34 \pm 0.71$ & 28.29 & 54.34 & 35.23 & 36.28 & 14.71 & 14.93 & 97.10 & 12.05 & 29.87 \\
\hline Pod yield per plant (g) & $139.18 \pm 4.55$ & 101.94 & 218.43 & 960.83 & 1003.75 & 22.30 & 22.76 & 95.70 & 62.47 & 44.85 \\
\hline
\end{tabular}

DAS - Days After Sowing

GCV - Genotypic Coefficient of Variation

$\mathrm{h}^{2}$ - Broad sense heritability

GAM - Genetic Advance as per cent of Mean
GV - Genotypic Variance

PV- Phenotypic Variance
PCV - Phenotypic Coefficient of Variation GA - Genetic Advance 
Table.3 Summary of genetic parameters of variability for various characters in thirty dolichos bean genotypes

\begin{tabular}{|c|c|c|c|c|c|}
\hline Characters & $\begin{array}{c}\text { GCV } \\
(\%)\end{array}$ & $\begin{array}{c}\text { PCV } \\
(\%)\end{array}$ & $h^{2}(\%)$ & GA & $\begin{array}{c}\text { GAM } \\
(\%)\end{array}$ \\
\hline Plant height $(\mathrm{cm})$ at Harvest & M & M & $\mathrm{H}$ & M & $\mathrm{H}$ \\
\hline No. of primary branches at Harvest & M & M & M & $\mathrm{L}$ & M \\
\hline No. of leaves per plant at Harvest & M & M & $\mathrm{H}$ & $\mathrm{H}$ & $\mathrm{H}$ \\
\hline Days to first flowering & M & M & $\mathrm{H}$ & M & $\mathrm{H}$ \\
\hline Days to 50 per cent flowering & M & M & $\mathrm{H}$ & M & $\mathrm{H}$ \\
\hline Number of flowers per cluster & M & M & $\mathrm{H}$ & $\mathrm{L}$ & $\mathrm{H}$ \\
\hline Days to first picking & $\mathrm{L}$ & $\mathrm{L}$ & $\mathrm{H}$ & $\mathrm{H}$ & M \\
\hline Number of pods per cluster & M & $\mathrm{H}$ & $\mathrm{H}$ & $\mathrm{L}$ & $\mathrm{H}$ \\
\hline Number of pods per plant & $\mathrm{H}$ & $\mathrm{H}$ & $\mathrm{H}$ & $\mathrm{H}$ & $\mathrm{H}$ \\
\hline Average pod weight (g) & $\mathrm{H}$ & $\mathrm{H}$ & $\mathrm{H}$ & $\mathrm{L}$ & $\mathrm{H}$ \\
\hline Number of seeds per pod & $\mathrm{L}$ & $\mathrm{L}$ & $\mathrm{H}$ & $\mathrm{L}$ & M \\
\hline Average green seed weight (g) & M & M & $\mathrm{H}$ & $\mathrm{L}$ & $\mathrm{H}$ \\
\hline Pod yield per plant (g) & $\mathrm{H}$ & $\mathrm{H}$ & $\mathrm{H}$ & $\mathrm{H}$ & $\mathrm{H}$ \\
\hline Shelling per cent $(\%)$ & M & M & $\mathrm{H}$ & M & $\mathrm{H}$ \\
\hline Pod length (cm) & M & M & $\mathrm{H}$ & $\mathrm{L}$ & $\mathrm{H}$ \\
\hline Pod width (cm) & M & M & $\mathrm{H}$ & $\mathrm{L}$ & $\mathrm{H}$ \\
\hline Pod thickness (mm) & $\mathrm{L}$ & $\mathrm{L}$ & $\mathrm{H}$ & $\mathrm{L}$ & M \\
\hline Weight of 100 seeds (g) & M & M & $\mathrm{H}$ & $\mathrm{M}$ & $\mathrm{H}$ \\
\hline Pod yield per plant (g) & $\mathrm{H}$ & $\mathrm{H}$ & $\mathrm{H}$ & $\mathrm{H}$ & $\mathrm{H}$ \\
\hline
\end{tabular}

Plate.1 General view of the experimental site

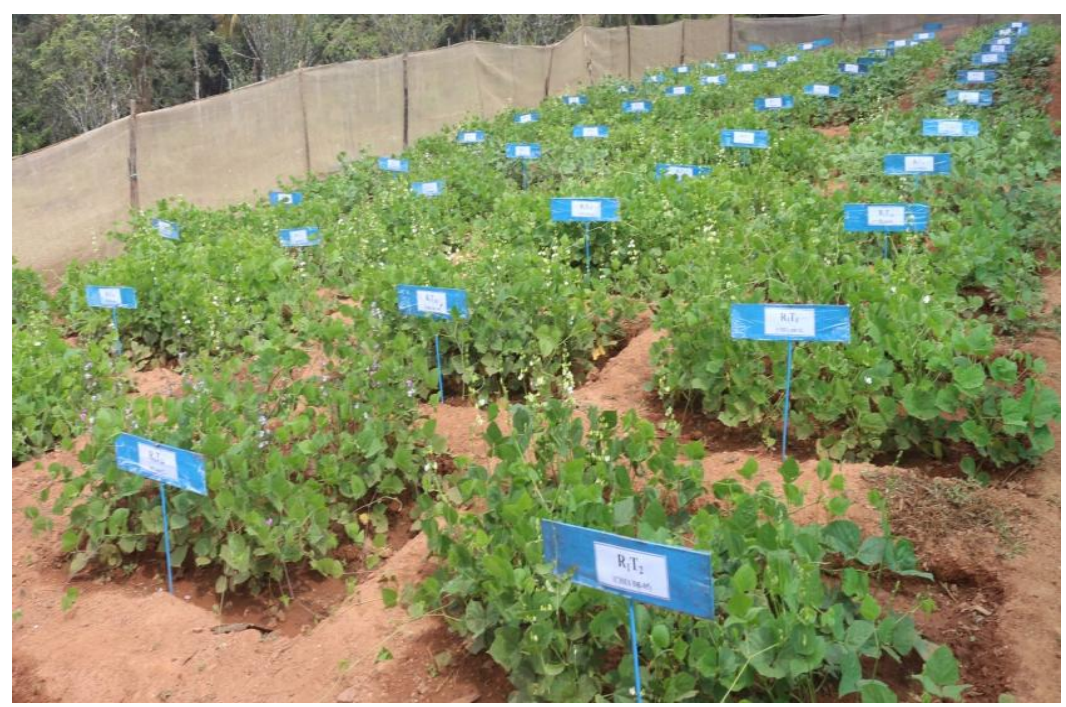


Among the different characters studied, high GCV and PCV were observed for number of pods per plant, average pod weight, pod yield per plant, It indicates the presence of higher magnitude of variability for these characters, which would be helpful for further selection. Moderate GCV and PCV were observed for plant height at harvest, number of primary branches at harvest, number of leaves per plant at harvest, number of flowers per cluster, days to first flowering, days to 50 per cent flowering, average green seed weight, shelling per cent, pod length, pod width and hundred seed weight. This indicates equal importance of additive and non-additive gene action in these traits. Low GCV and PCV were noticed in days to first picking, number of seeds per pod and pod thickness which had narrow genetic base for these traits (Table 2). Hence variability has to be created in these traits can be done by either through introduction or by hybridization between divergent parents (Table 2). These results are in conformity with the findings of Chaitanya et al., (2014), Verma et al., (2015).

Close relationship between $\mathrm{GCV}$ and PCV was found in all the characters and PCV values were slightly greater than GCV indicating a very little influence of environment for their expression (Table 2). This is in confirmation with the results reported by Chaitanya et al., (2013), Goudar et al., (2017), Verma et al., (2015), and Noorjahan et al., (2019).

Only the extent of variability present in genotypes for different characters is indicated by coefficient of variation but for the prediction of response to selection heritability estimates are useful. Since heritability is a important factor for expressing the phenotypic variability value as a tool to breeding value. Hence Heritability is a fundamental important factor in practicability of selection.
High broad sense of heritability (> $60 \%$ ) was shown by plant height at harvest, number of leaves per plant at harvest, days to first flowering, days to 50 per cent flowering, number of flowers per cluster, days to first picking, number of pods per cluster, number of pods per plant, average pod weight, number of seeds per pod, average green seed weight, pod yield per plant, shelling per cent, pod length, pod width, pod thickness, hundred seed weight (Table 2 and 3 ).

The high estimates of heritability coupled with high genetic advance over per cent of mean were observed for traits such as a plant height at harvest, number of leaves per plant at harvest, days to first flowering, days to 50 per cent flowering, number of flowers per cluster, pod length, pod width and pod thickness, number of pods per cluster, number of pods per plant, average pod weight, average green seed weight, pod yield per plant, pod yield per plot, pod yield per hectare and shelling per cent, which indicates that these characters are under the influence of additive gene action similar results were also obtained by Chaitanya et al., (2014), Verma et al., (2015), Hadavani et al., (2018), Susant and Bahadur (2018) and Noorjahan et al., (2019).

In conclusion the ssignificant differences were observed among the genotypes for all the characters studied at five per cent level of significance. Components of variation exhibited by the genotypes for all the characters indicated wide range of variability present in the genotypes.

High to moderate GCV and PCV were observed by the most of the characters studied, and most of the characters exhibited high heritability coupled with high genetic advance as per cent of mean which indicates that these characters are under the influence of additive gene action. 


\section{References}

Ayyangar, G.N.R. and Nambiar, K.K.K. 1935. Studies in Dolichos lablab ((Roxb) and (L.)) the Indian field and garden bean. The First Proceedings of Indian Academy of Science. 1(12): 57-867.

Burton, G.W and Devane, E.M. 1953. Estimating heritability from replicated clonal material. Agronomy Journal. 45: 478-81.

Chaitanya, V., Reddy, R.S.K. and Kumar, P.A. 2014. Variability, heritability and genetic advance in indigenous dolichos bean (dolichos lablab Var. typicus) genotypes. Plant Archives. 14(1): 503-506.

Chaudhari, J., Kushwah, S.S., Singh, O.P., And Naruka I.S. 2016. Studies on genetic variability and character association in Indian bean [Lablab purpureus (1.) sweet]. Legume Research. 39(3): 336342.

Goudar, R., Srinivasa, V. and Lakshmana, D. 2017. Genetic variability and genetic divergence in cluster bean [Cyamopsis tetragonoloba (1.) Taub] under hill zone of Karnataka, India. Legume research. 40(2): 237-240.

Hadawani, J.K., Mehta, D.R., Raval, L.J. and Ghetiya, K.P. 2018. Genetic variability parameters in Indian bean (Lablab purpureus L.). International journal of pure and applied bioscience. 6(4): 164168.

Johnson, H.W., Robinson, H.F. and Comstock, R.S. 1955. Estimation of genetic and environmental variability in soyabean. Agronomy Journal. 41: 314-318.
Noorjahan, A. M., Deshmukh, J. D., Wankhade, M. P. and Kalpande, H. V., 2019. Genetic variability, heritability and genetic advance studies in dolichos bean (Lablab purpureus L.). Int. J. Chem. Stud., 7(3): 479-482.

Panse, V. G. and Sukhatme, P. V. 1967. Statistical methods for agricultural workers, $2^{\text {nd }}$ edition ICAR, New Delhi. pp. 324

Pokel, Y.S. and Deshmukh, N.N. 1972. Keel cap - a new method of pollination in papilionaceous flowers. P.K.V. Research. Journal. 1(1): 137-139.

Ram, B.K.C., Joshi, B.K. and Dahal, S.P. 2016. Diversity analysis and psychomorphological characteristics of indigenous germplasm of lablab bean. Journal. Nepal. Agriculture. Research. Council. 2(15-21): 2392-4535.

Susanth, S. and Bahadur, V. 2018. Genetic analysis of dolichos bean (Lablab purpureus L.) genotypes for horticultural traits. Journal of pharmacognosy and phytochemistry. 7(4): 3112-3116.

Verma, A.K., Uma Jyothi, K and DorajeeRao, A.V.D. 2015. Variability and character association studies in dolichos bean (Lablab purpureus L.) Genotypes. Indian Journal of Agriculture Research. 49 (1): 46-52.

Weber, C.R. and Moorthy, H.R. 1952. Heritable and non-heritable relationship and variability of oil content and agronomic characters in the $\mathrm{F}_{2}$ generation of soybean crosses. Agron. J., 44: 202-209.

\section{How to cite this article:}

Shilpa, M. L., V. Srinivasa, Devaraju, S. Gangaprasad, M. Ganapathi and Akshay, A. 2020. Variability, Heritability and Genetic Advance for Yield and Yield Attributing Characters in Dolichos Bean (Dolichos lablab L.) Genotypes under Hill Zone of Karnataka. Int.J.Curr.Microbiol.App.Sci. 9(10): 201-207. doi: https://doi.org/10.20546/ijcmas.2020.910.026 